\title{
The Effect of Al-Andalus and Mashriq Bilateral in the Production of Andalusian Creative Poetry
}

\author{
${ }^{1}$ Assist. Prof. Dr. Hadi Taleb Mohsen Al-Ajili \\ College of Education for Human Sciences/ University of Babylon
}

\begin{abstract}
From the time of the Muslim Arabs, the Iberian Peninsula "Iberia" (Spain and Portugal), when the Arab conquerors entered it, became the center of scientific and cultural enlightenment for more than eight centuries, which the Arab Islamic State has experienced since the Umayyad era, passing through the kings of the sects. Rich in creativity and paper and beauty has been seen several factors for the prosperity of the literature of the people of Andalusia and the quality of the product of poetry in particular of these factors social environment luxury was the culture Didnhm was mourning and Ibn al-Bazaz and Ibn al-Jazzar buy and nonpurchase taste the Yan for representation is not secret, as well as the negative impact of influence has God endowed. In addition to this, the most important and distinctive factors are the rivalry between Mashreq "The Eastern Part of the Arab World, Countries Bounded between the Mediterranean Sea and Iran" and Andalus, the rivalry that characterized the Arab Muslim identity as an Andalusian literary identity derived from the alternative home. The Orient, but encouraged the rulers of Andalusia - most of them poets - this competition to be positive integrative not only because the designated one is the language of the Koran and common broad religious and national at the same time. It is not clear from this point of view that this research is influenced by the influence of the two oriental and the Andalusian in the creative work of Andalusia. Andalusia, and the intention to compare the environment has lost in the writings of many. But an attempt to trace the positive impact generated by the bilateral East and Andalusia was the birth of a creative poetic and creative, and what positive manifestations of the bilateral on the poets of Andalusia to compare the segments of the flowers in this area? The bases of the research revolve around the statement of the factors of cross-fertilization between the two houses and then the manifestations of the positive bilateral stood at the titles of poets Andalusians, Al-Gazal, Abu Nawas and IbnHazm and preference of the Mashreq and Ibn Abed Rabbo and Mutanabi and IbnShahid and his aides and calamities.
\end{abstract}

Article Received: 18 October 2020, Revised: 3 November 2020, Accepted: 24 December 2020

\section{Introduction}

Bilateral (Binary) is an innate behavior in human life, so the life, death, love, hating, good and evil are an innate behavior. It may be say that all the aspects of life are as a result of that attraction among this binary. So, the ideological attraction and binary has a great effect, which makes the relationship between them dialectical, there is no need to human thought without binary, i.e. binary is two or more parallelism relations that aims to integration and to end the lifeblood in all its aspects, so in the literature of Al-Andalus and Mashriq it was have a parallelism attendance but not binary converseness that takes the related antonymy field, which aims to the integration, growth, creation and creativity of Arabic literature (Al- Diop, Samr: Binary Converseness: A Study in Semantics and Pragmatics, Samr Al-Diop, Islamic Centre for Strategic Studies, $1^{\text {st }}$ edition, 2017/40).
The cultural progress, the progress of civilization and the progress of thought in all the fields of knowledge in Al- Mashriq has a reflective and positive effect in the Arab and Islamic culture. AlAndalus has a good role, which contributed of showing this effect that represented in its The cultural progress, the progress of civilization and the progress of literature specifically. AlAndalusian literature is a great literature that continued to eight centuries, the characteristics of Andalusian literature were clear and gotten its specific identity by using cultural, linguistic and literary accumulation, so the most important characteristic was that taken from ancestral through these eight centuries. The Andalusian literary character was associated with beauty, polite, and creative. The distinct nature was the biggest distinction, therefore, the relationship between AlAndalus and Mashriq was characterized by crosspollination, which had helped to its literary 
production with its two aspects prose and poetry because they believed that al-Mashriq is the motherland which they were emigrant from but they wish to go back because of religious and sentimental reasons, so the model of Mashriq remained an honorable example to follow throughout the periods of Andalusia.

\subsection{Al-Mashriq and Al-Andalus (Cross- fertilization of Idea)}

There's been a lot of talk about the comparison between the literature of Al-Mashriq and Andalusia, due to the historical, religious and cultural value suppalone and the sources of this common and the one appointee from which the writers of the two cultures were derived from the Arab-Islamic culture, demonstrated in the introduction of the glorious Quran, and it is no secret to the follower that the religious thought carried by Al-Thikr Al-Hakim and its meanings in all its values and its means have speared in all fields of life, poetry was one of those fields (Bahjat, Dr. Munjed Mustafa, The Islamic attitude in Andalusian poetry during The Almoravid dynasty and the Taifas Period, $1^{\text {st }}$ edition, Beirut, 1986, 12). The Arab poet is moving between the holy qur'an and his optimal artistic models, language, composition, taste and all aspects (Al-Tayeb: Abu Sheba, the Effect of the Glorious Qur'an in the Artistic Image of the poets of Islamic Era, p. 91). Moreover, Andalusia has not stopped from the legacy of ancestors, pre-Islamic poetry and prose arts, so they have seen it, as well as genealogy, philosophy and other fields of knowledge, and do not forget the movement of scholars, students of science and art media between al-Mashriq and Andalusia and vice versa (al-Maqqari alTalmasani, Shihab al-Din Aḥmed ibn Muhammad al-Maqqari al-Talmasani who has died in 1041A., The Breathing of the Perfume of the wet Andalusian Branch, Lisan Al-Din Ibn Al-Khatib, edited by: Ihsan Abbas, Dar Sader, Beirut, $1^{\text {st }}$ edition, 1997, 3/140.

The competition has encouraged the governors of the literary movement to have the books of alMashashara as al-Mustansir did, and he has got The
Book of Songs, so it is clear that al-Bustani shows that in his book "The Arabic Literati in AlAndalus": "Andalusian people have learnt everything about poetry knowledge, types, aims and arts, including what the people of Al-Mashriaq have characterized in their meanings, also they shared them their common poems. Some of these poems have used a special nature and have used to describe nature, buildings and lamenting the ancient Kingdoms" (al-Bustani, Butrus: The Arabic Literati in Al-Andalus and the Age of Emancipation, Beirut, no date, 40).

\subsection{The Manifestations of Al-Andalus and Mashriq Bilateral on Andalusian Poetry}

At the beginning, the relationship between Mashriq and Andalusia was a simulation and followed and complained about the first generation, but in other Andalusian periods became a relationship of bilateral rivalry, coexistence, exchange and show of ingenuity and a match to reach the climax by monitoring the creativity of the people of alMashriq and producing similar in al-Andalus in a positive way, which emphasized on the positive effect that both two literatures have been written in Arabic language. Moreover, the relationship was strong, close and continuing between al-Mashriq and al-Andalus, especially at the scientific and cultural level. Whereas, the groups of scholars and writers were going from al-Mashriq to al-Andalus and vice versa (Al-Matrifi, Dr. Faizah: The Andalusian Literature, Umm Al-Qura University (UQU), No date, $1^{\text {st }}$ edition).

This was reflected in the field of Andalusian poetry in its systems and criticism, there is a creative product of poetry and then there is what was said by the monetary provisions that the Andalusians continued to be proud of because they rewarded its creators and became certificates of creativity and excellence. Moreover what carried the introductions of the poets of Andalus, including ibn Khafaja, who is Ibrahim ibn Abi al-Fath bin Abdullah bin Khafaja al-Andalusi, he was known as Al-Gazal and description of nature, he was born in 1945 and died in 533A., his diwan poetry has shown that "he was interested in some poets of al- 
Mashriq and he has influenced by his simulation with them" (for more details: Al-Andalusi, Ibn Khafaja, The Diwan of Ibn Khafaja Al-Andalusi, Investigated by Sayyid Ghazi, Dar-almaaref, Alexandria, 1960, Introduction).

In the present study, the researcher tries to focus on the most important incidents, phenomena and critical attitudes that were a motivation to creativity, starting with the nicknames of Andalusian poets, the psychological attitude between Al-Gazal and Abu Nawas, Ibn Hazm's Crying, the preference of al-Mashriq, and the admiration of al-Mutanabbi with ibn Abd Rabbih.

\section{Nicknames of Andalusian Poets}

It is no accident that the poets of Andalusia are called the poets laureate of al-Mashriq, it is very important to that the Andalusian poet is alike to the poets of Mashriq who is nicknamed as the product in quantity and quality. Moreover, the nickname that given is a critical judgment given by period in order to make meeting between the two poets with quality, workmanship and poetic orientation, the objective contents and methods of art.

When Abu al-Khattar al-Kalbi was nicknamed as Antarat al-Andalus, Ahmed was nicknamed as Dik Tis al-Jinn al-Alandals, Hamdouna bint Ziad was nicknamed as the women of Morocco, Ibn alLabbana was nicknamed as Samaw'al of poets, Ibn Darraj al-Qasțalli was nicknamed as al-Mutanabbi of Andalus, Muhammad ibn Hani al-Andalusi alAzdi was also nicknamed as al-Mutanabbi of Andalus, Ibn Zaydun was nicknamed as Buhtri alAndalus, Abu Bakr al-Ashboni nicknamed as Abu Firas al-Hamdani, al-Rusafi al-Balansi was nicknamed as Ibn Rumi al-Andalus and Marwan ibn Abdel Rahman was nicknamed as Ibn Moataz al-Andalus, (for more details looking for: The Nicknames of the Moroccan and Andalusian Poets, Abul Hassan Ali bin Musa bin Said, who has died in 685 A., Morocco is the sweetest of Morocco, edited by: Dr. Shawky Dhaif, Cairo, $3^{\text {rd }}$ edition, 1955, 1/131 and 2/411). The order has been withdrawn by the politics and nicknames of the caliphs, such as Al-Nasir li-Din Allah, al-Mustansir li-Din Allah, Al-Musta'in bi-llah, Al-Zafir, Al-
Mutawakkil...etc., the poetic nicknames are used to critic the period, and it is represent a view of criticism that aims to metaphor between the Andalusian poets as well as the tendency of unity in the cultural field and literary resource.

3. Abu Nuwas and Al-Gazal (Yahya bin alHakam al-Bakri al-Gailani)

Yahya bin al-Hakam al-Bakri al-Gailani who was known as Al-Gazal, he was an Andalusian poet who lived for five Emirs of Umayyads, and he said:

\section{I've lived with five Emirs of Umayyads}

\section{One of them is who we are living with now}

The first one is Abd al-Rahman Ibn Muawiyah and the last one is Muhammad bin Abd al-Rahman Ibn al-Hakam (al-Muqri al-Tilmisani, Shihab al-Din Ahmad bin Muhammad al-Muqri al-Tilamisani who has died in 1041 A., A Good Whiff of AlAndalus Branch, Al-Khatib and his minister mentioned to Lisan al-Din bin al-Khatib, edited by: Ihsan Abbas, Dar Sader, Beirut, $1^{\text {st }}$ edition, 1999 $\mathrm{AD}, 2 / 254)$, who has praised them, and described him as handsome, cute, polite and talkative.

The poet was exposed to many situations, horrors and he has been getting older, he was the poet of the palace and took over the embassy, and then he was imprisoned after a conflict and rivalry between him and Zaryab, and his life fluctuated between intensity, prosperity, optimism and pessimism. $\mathrm{He}$ was nicknamed as "Al-Gazal" for his beauty, who is the poets of the third hundred of Bani Bakr bin Wael (Al-Magari Al-Tlemsani, Nafh al-Tayeb, 7/754).

What matters to us is that his poems carried the facts of his life, including the incident of his travel to al-Mashriq, he was forced to leave until he arrived to Iraq, and he was carrying a common obsession with Andalusian poets, which is to fight al-Mashriq poets in poetry, privilege and creativity is right, he has compared his poetr y to Abu Nawas' poetry, he has mentioned his incident with the followers and fans of Abi Nawas. The author of the book of the singer from the notice of the people of Morocco Ibn Dahia al-Kalbi, who has shown to us the incident of Al-Gazal in some details, and he has 
said: "Then Al-Gazal was not feeling comfortably in Andalusia and he left to Iraq in a bit after the death of Hassan bin Hana, and he found that they always say his poems as well as they considered his poems are the pest, one day he has sat with some of them, they supported Al-Andalus and they deplored their poetry, and he has been waiting for them until they mentioned al-Hassan, and he said to them: "who memorize what he was said?" ( AlKalabi al-Andalusi, Abo Khatab Omar bin Hassan who has known as abi Diha al-Kalabi who has died in 633 A., The singer of the poetry of Morocco, edited by: Mr. Ibrahim al-Biari, et al., Dar al-Alam, Beirut, 1955, 1/148) (al-Mqri, The Breathing of Perfume, 2/261).

When I saw that the wine had run out,

I held my bowl under my arm and endured my suffering

When I reached the Pub, I called the owner

So, the Light-spirited jumped up towards my call

He sleeps a little at night, except for what is caused by it

\section{Afraid of me and my counterparts}

They admired the poetry and went in praising him for all the school of thought, and when they went too far, he said to them: Calm down, this is for me, but they didn't believe that, and then he said his poem which begins with:

\section{I have obviated my sins in wine drinking}

And I've left my shameless

When he has ended his poem, they were ashamed of (Al-Kalbi Al-Andalusi: Al-Shahir Ibn Ibn Dihya, 1/148).

The tracer of the incident motivations that was a manifestation of cultural participation between the poets of al-Mashriq and al-Andalus, because of there are full comparability between Andalusian poet and Mashriqi poet in the way of writing and stylistic characteristics and the lexical meanings to the extent that it is difficult to distinguish between them. So, the poet aims at proving creativity, efficiency and symmetry. It was a catalyst for his/her product and creativity of his/her writing to get a positive aim, which is creation and attachment between the two poets with competence and poetic ability.

\section{The Art of Arabic Prosody}

\subsection{The Lexical Meaning of Arabic Prosody}

Ibn Mandhur has stated in his book "Lisan al-Arab "the tongue of the Arabs" that "polemic poetry lexically means interview, it is said that polemic is considered as interview. Come with him/her in walking, which means come to him/her with what he come with (For more details: Ibn Mandhur alAnsari, Lisan al-Arab 'the tongue of the Arabs, who has died in 711 A., Beirut, $3^{\text {rd }}$ edition, 1414 A., (Arabic prosody), 7/186).

\subsection{The Contextual Meaning of Arabic Prosody}

It is "the simulation of literati of his/her literary effect on another literati, which refers to his/her skill" ((Wahba, Majdi Kamel: Dictionary of Arabic Terms in Language and Literature, Beirut, $1^{\text {st }}$ edition, 1984: 371).

\section{Ahmed ibn Muhammad ibn Abd Rabbih} and Abu al-Tayyib Ahmad bin Al-Husayn alMutanabbi al-Kindi

He is Ahmed ibn Muhammad ibn Abd Rabbo alAndalusi born in $246 \mathrm{Ah}$ and grew up in Cordoba connected to the scholars of his time and is an encyclopedic poet and writer with a poetry book and is nicknamed the Andalusian Méllih and his most prominent books are the unique contract (The Repercet quoted in the mention of the Andalusian Scholars, Cairo, 1966, 171). He is Ahmed ibn Muhammad ibn Abd Rabbo al-Andalusi born in $246 \mathrm{Ah}$ and grew up in Cordoba connected to the scholars of his time and is an encyclopedic poet and writer with a poetry book and is nicknamed the Andalusian Méllih and his most prominent books are the unique contract (The Repercet quoted in the mention of the Andalusian Scholars, Cairo, 1966, 171). He is Ahmed ibn Muhammad ibn Abd Rabbo al-Andalusi born in $246 \mathrm{Ah}$ and grew up in Cordoba connected to the scholars of his time and is an encyclopedic poet and writer with a poetry book and is nicknamed the Andalusian Méllih and his most prominent books are the unique contract (The Repercet quoted in the mention of the Andalusian Scholars, Cairo, 1966, 171). There was a lot of literary controversy about the book and its name between the contract or the unique contract 
or the garlic rope derogatory from the opponents, and Ibn Abd Rabbo mentioned in the introduction to the book where he says (and named the unique contract for its various jewels with the accuracy of the wire and the good order) (Ibn Abd Rabbo and the good of the system) (ibn Abd Rabbo and the Andalusian Abu Omar Shihab al-Din Ahmed bin Mohammed bin Abd Rabbo ibn Habib Ibn Hadir bin Salem: The unique contract (deceased $328 \mathrm{H}$ ), Beirut, t1, 1404h, 6/245)Ibn Abd Rabbo mentioned in the introduction to the book that he mentioned the unique contract of various jewels with the accuracy of the wire and the good of the system) (Ibn Abd Rabbo of Andalusia, Abu Omar Shihab al-Din, Ahmed ibn Mohammed bin Abd Rabbo, ibn Habib ibn Hadir bin Salem: The Unique Contract (who has died in 328 A.), Beirut, t. 1, 1404h, 6/245).

The contract was accompanied by the saying of Sahib Ibn Abad after he read it (these goods replied to us, I thought that the book included the news of their country - and i.e. Andalusia - but it is a part of the news of our country, we do not need him to do so) as well as what the ibn al-Qaflat said, mocking and mocking ibn Abd Rabbo and his contract. 2/294) (Seen: Zamera, Abdul Qadir, poet Ibn Abd Rabbo, Baghdad, Al-Mord magazine, Baghdad, 1977, 6/2/42) distortion and disparaging because of the encounter between them, as well as the name of the writer Ibn Abd Rabbo is associated with his incident of poetry with the Prophet and his leg opinion in it and mentions that al-Walid is ibn When he left hajj, he met with Abu al-Tayeb in the Mosque of Amr ibn al-As in Egypt, and he negotiated it a little, and then he said to him, "Sing me for the salj al-Andalus, i.e. Ibn Abd Rabbo."

Pearl, give minds a neat, soul-taweed, and a companion.

As soon as i saw or heard of it, dra comes back from shyness.

And if you look at the pros of his face, you look at your face in a strange tooth.

Whoever cut his waist from a parchment in your heart isn't thin.

When he completed her song, he regained it and then clapped his hands and said, "O Ibn Abed
Rabbo, Iraq has come to you, they have loved" (AlMuqari, Al-Nahh, 5,565). Ibn Abd Rabbo has charmed al-Mutanabbi in his language and style.

If I may link the two incidents with the motives of writing a unique contract book and his poetry incident with al-Mutanabbi, dr. Mandad Mustafa Bahgat the motives of writing the book that in order to introduce the people of al-Mashriq to the poets of Andalusia and vice versa and to strengthen the confidence of the Andalusians themselves (Bahgat, Manjed Mustafa: Andalusian literature, 112), these are the motives of the book's apparent composition, but the end of the same poet that he was not walking in the passengers of the sharqiya only, but he was opposed to them and aimed to outdo them and was driven by his vast literary culture and ambitious Andalusian spirit, and yet all of his ibn Abd Abd took the meanings of the stripes only, and he was driven by his vast literary culture and his ambitious Andalusian spirit, and yet all of his ibn Abd Abd took the meanings of the stripes only, and he was driven to the ground. He tried to prove his ability to come up with the same or better ones, and he did not take for himself an imam of the Orient poets in every art, but he opposed these imams to prove that he is like them or better than them, and he showed this in his book The Unique Contract: "Whoever considers the ease of this poetry with the exquisite meaning of his printing paper, he did not separate the poetry of Sa'a'aal al-Gowani only because of progress, especially if he is associated with his saying in this poetry( Ibn Abd Rabbo, the unique contract, 6/246).

The aim is to bring his poetry, which represents the Andalusian side (argoste in 1,400 houses) between the poets involved and the poets of his Andalusian generation, such as the poet Ghazal, Abbas Ibn Farnas and Ibn Said, is nothing but an attempt to put the reader in the field of criticism and opinion, and leaves him a monetary space to pair the poetry of ibn Abd. His Lord is the one who is the one who is the one who is the poet of his time and the poets of his time to say afterwards (and i compared the strangeness of my poetry to the knowledge of the beholder in our book, if we do not hit us (Andalus) on his story and our country on his interruption of 
luck from the system and the revolution) the uniqueness of the contract is the uniqueness of his hair as if it were the medium of the contract between the two sides of the contract Represented by the poets of the Orient and the poets of Andalusia on both sides, the purpose of the book was to write the same book itself (the unique contract).

6. Abu Muḥammad 'Ali ibn Ạ̣med ibn Saaid ibn Hazm and the Monorhyme

$\mathrm{He}$ is Abu Muhammad Ali bin Ahmed bin Hazm al-Alandalasi al-Qartabi al-Dhahrabi al-Dhahir in relation to his birth and his apparent doctrine, the jurisprudence of Andalusia and its scientist, the author of the descriptions in literature, controversy, jurisprudence and judgments, a brilliant poet and writer with a poetry book and his book The Ring of the Dove is the most important description and has a message in the virtues of the Andalusian people: in it they said (he gathered all Andalusianpeople for the sciences of Islam and the broadest knowledge with his expansion in the science of the tongue and his luck of communication, poetry and knowledge of biography and news) (Ibn Boushqq). 578H), Link, Egyptian House of Authorship, 1966, 2/416) Ibn Hazm was the most proud Andalusian poet of their creativity, but a look at the depths of his poetry shows clearly that he is obsessed with the stupidity of his position, which remained trapped in his chest, even if he was crowded by a cry in his poetry to say (Andalusian, Ibn Hazm (T. 456H), Diwan Ibn Hazm al-Andalusi collected and achieved Abdul Aziz Ibrahim, Dar Sader, Beirut, i.e. 2010, 35):

I'm the sun in the light of science, but my eyes are that the eyes of the West.

And if I were on the east side, I'd find out what $i$ lost in my memory of looting.

He goes from allusion to the statement to show us his poetic verses that andalusian poets are no less brilliant than the poets of al-Mashriq, and he reminds himself among the special and wants to show here that he is no less brilliant than alMashriq, but his only flaw mentioned in his poetic verses is that he is "the beginning of the West", not the East, and that The only difference between him and the poets of al-Mashriq is his Moroccan upbringing only, and the difference between them was not due to literary prowess or poetic workers or other than what we see the interest of poets through the ages and times. The motive for creativity and innovation is the motive for creativity and innovation that made him the partner of al-Mashriq, a note and a literature, and he addressed Ibn Hazm with these verses, the judge of the group in Cordoba, Abderrahmane ben Ahmed, where we find him proud of science and mentions the varieties of what he learned (Hamidi, Jaja quoted in the mention and not Andalusia, 310).

Their only approach or sole goal was not only to emulate and imitate the poets of al-Mashriq, but also to distinguish and uniquely the poets of alMashriq as well.

\section{Results and Conclusions}

The bilateral of Al-Andalus and Mashriq has been represented in poetry and poets as an increase of production poetry in Al-Andalus positively, at the same time the Andalusian poets have interested in all literature sciences of poets and poetry in alMashreq "The Eastern Part of the Arab World". Al-Andalus and Mashriq Bilateral in Arabic poetry was not limited to simulating and imitating Andalusia and then following the example of the poets of al-Mashriq in the quality of poetry and its production, but the expansion of the vision of the poets of Andalusia to innovation and discrimination and then uniqueness and renewal on what the poets of al-Mashriq came up with as a result of what they saw on it is the product of alMashriq from their own poetry and their literature in general.

The prosody between the poets of al-Andalus alMashriq has led to the transition from the role of admiration and simulation to the love of progress and innovation.

This Bilateral, with its framework and positive content, was motivated by creativity, sophistication and artistic production, which attracted the connoisseur of the beauty of poetic art and to 
determine its quality, formulation and artistic image.

We must draw the attention of researchers to the sign of convergence and coexistence and to positive community and follow creative secretions that do not follow the different and exclude the others the literature of two environments of one nation based on its language the Holy Quran.

The subject can be studied academically in graduate studies in more detail and statement than our research was limited to this.

\section{References}

[1] Diwan Ibn Hazm al-Andalusi (456 A.): Collecting and investigating Abdul Aziz Ibrahim, Dar Sader, Beirut, $1^{\text {st }}$ edition, 2010.

[2] The Islamic attitude in An dalusian poetry during The Almoravid dynasty and the Taifas Period: Dr. Munjed Mustafa Bahjat, 1st edition, Beirut, 1986.

[3] Andalusian literature from the conquest until the fall of the caliphate: Dr. Munjed Mustafa Bahjat, Ministry of Higher Education, Mosul University, 1987.

[4] Arab writers in Andalusia and the Era of Rebirth: Boutros Al-Bustani, Dar Nazir Abboud, Beirut, No Date.

[5] The History of Andalusian Literature, The Era of The Rule of Cordoba: Dr. Ihsan Yas, House of Culture, Beirut, Lebanon, 7th Edition, 1985.

[6] Anti-binary studies in the term and significance: Samar Al-Deoub, Islamic Center for Strategic Studies, $1^{\text {st }}$ edition, 2017.

[7] The quoted in the mention of the Andalus Governors: Muhammad bin Fattouh bin Abdullah bin Fauht bin Hamid al-Yazdi alMu's al-Hamidi Abu Abdullah bin Abi Nasr (who has died in 488A.), The Egyptian House of Authorship and Publishing, Cairo, published in 1966.

[8] Diwan Ibn Khafaja al-Andalusi: The Investigation of Sayyid Ghazi, Dar alMa'araf, Alexandria, 1960.
[9] Diwan ibn Shahid al-Andalusi and his message: The Realization of Mohammed Mohieddin, Modern Library, First Edition, Sidon, Beirut, 1997.

[10] Diwan al-Arab: Dr. Ayd Abdullah al-Qarni, Al-Abikan Library, 1430A, Indexing of the National King's Library during publication, Fifth Edition, Riyadh, 1430 A.

[11] Ammunition in the merits of the people of Al Jazeera: Abu al-Hassan Ali bin Bassam al-Shantrini (who has died in 542 A.), Investigation of Ihsan Abbas, Arab Book House, Libya- Tunisia, first edition, 1981.

[12] The Unique Contract, Abu Omar Shihab alDin Ahmed bin Mohammed bin Abd Rabbo, ibn Habib ibn Hadir ibn Salem, known as Ibn Abd Rabbo al-Andalusi (who has died in 328 A.), The House of Scientific Books, Beirut, first edition, $1404 \mathrm{H}$.

[13] The poet Ibn Abd Rabbo Abdul Qadir Zamera: Baghdad, Al-Mord magazine, Baghdad, 1977, Vol. 6, No. 2.

[14] Tongue of the Arabs: Muhammad bin Makram bin Ali Abu al-Fadl Jamal al-Din, ibn al-Ansari al-Rawifai al-Afrihi (who has died in 711 A.), Dar Sader, Beirut, third edition, 1414 A., article (Prosody).

[15] The singer of the poetry of the people of Morocco: Abu Khattab Omar Ben Hassan al-Andalusi, alias Ibn Dahia al-Kalbi (who has died in $633 \mathrm{H}$ ), by The Investigation of Professor Ibrahim Al-Abiari, Dr. Hamed Abdel Majid, Dr. Ahmed Ahmed Badawi, reviewed by Dr. Taha Hussein, Dar alAlam for Printing, Publishing and Distribution, Beirut- Lebanon, 13 74H1955.

[16] Dictionary of Arabic terms in language and literature: Magdi Wahba, Kamel AlMuhandis, Library of Lebanon, Beirut, second edition, 1984.

[17] Morocco in The Ornament of Morocco Abul Hassan Ali ben Moussa bin Said Moroccan Andalusian (who has died in 685 A.), Dr. Shawky Dhaif, House of Knowledge, Cairo, third edition, 1955. 
[18] Nafeh al-Tayeb from The Branch of AlAndalus Al-Riftab: Its Minister, San alKhatib, mentioned The Ahmed bin Mohammed al-Magari al-Tlemceni (who has died in1041 A.), Ihsan Abbas, Dar Sader, Beirut, Lebanon, first edition, 1997. 